\title{
Status of Soil-Transmitted Helminthic Infection in Nepal
}

\author{
Shiba Kumar RAI'), Takashi KUBO ${ }^{2)}$, Mamoru NAKANISHI'), Katsumi SUMI ${ }^{3)}$, \\ Hiroshi SHIBATA ${ }^{3)}$, Akira MATSUOKA ${ }^{3)}$ and Hari Govinda SHRESTHA ${ }^{1)}$ \\ ${ }^{11}$ Department of Pathology, Tribhuvan University Teaching Hospital, Kathmandu, Nepal \\ ${ }^{2}$ JICA Medical Education Project, Tribhuvan University Teaching Hospital, Kathmandu, Nepal \\ ${ }^{3}$ Department of Clinical Pathology, Hyogo College of Medicine, Hyogo, Japan \\ (Received: January 7, 1994) \\ (Accepted: February 7, 1994)
}

Key words: helminths, soil-transmitted, Nepal

A retrospective evaluation of the status of soil-transmitted helminthic infection in Nepal during the period from 1985 to 1992 was conducted at the Parasitology Laboratory, Department of Pathology, TU Teaching Hospital in Kathmandu. An average of 6,537 faecal samples were examined each year for the presence of various types of intestinal parasites. The annual rate of positivity of these samples for soiltransmitted helminthiasis ranged from 18.0 to $36.6 \%$. The annual incidence decreased every successive calender year in both adults and children, irrespective of sex. Among the various types of helminths, the most common was Ascaris lumbricoides (roundworm), followed by hookworm. The incidence of $A$. lumbricoides remained constant throughout the study period, while that of other parasites markedly decreased each year.

\section{Introduction}

Soil-transmitted helminthic infection is one of the major public health problem in the world, particularly in developing countries ${ }^{1,2}$. A. lumbricoides (roundworm), hookworm (Ancylostoma duodenale and Necator americanus) and Trichuris trichiura (whipworm) are the most common soil-transmitted helminths (STH) which infect man. Twenti-five percent of the world's population is estimated to have been infected by one or more species of these parasites ${ }^{3}$. A. lumbricoides, hookworm, and T. trichiura have been estimated to parasitically infect 1 billion, 900 million, and 500 million people, respectively, in the world ${ }^{4}$. These parasitic infections are the major cause of morbidity in developing countries ${ }^{5)}$ and are also responsible for mortality in areas with limited health care delivery ${ }^{1}$.

The reported incidence of STH infection in Nepal varies from one study to another,5,6,8,9,10,11). A. lumbricoides is the most common STH, and children are more commonly infected than adults ${ }^{6}$. However, no reports are available regarding the yearly change in the incidence of STH infection in Nepal. We therefore carried out a retrospective study to evaluate the status of STH in Nepal during the eight-year period from 1985 to 1992 using the hospital records maintained at the Parasitology Laboratory, Department of Pathology, TU Teaching Hospital, Kathmandu. Hospital records are increasingly popular method in finding out the incidence of intestinal parasites ${ }^{12)}$. The present report is the first of its kind from Nepal.

\section{Materials and Methods}

In this retrospective study, hospital records were used as the source of the data. The study population was defined as all who submitted their faecal samples for the detection of intestinal parasites during the 8

別刷請求先：（兵663）西宮市武庫川町 $1-1$

兵庫医科大学病院臨床病理学

柴田宏 
year period from 1985 to 1992 . The faecal samples had been examined both macroscopically and microscopically. The microscopic examination had been performed using saline and iodine preparations, and the concentration technique (Formal-Ether sedimentation) had been employed only in doubtful cases. Actively moving larvae were immobilised before identification. During this period, no individual submitted three consecutive samples. The data were analysed to determine the annual incidence of STH infection for adults (more than 15 years) and children (15 years or less) of each sex.

\section{Results}

The average number of faecal samples examined each year of the study period was 6,537 . The over all annual rate of positivity for STH ranged from 18.0 to $36.6 \%$, and a marked pattern of year-to-year decrease was observed (Fig. 1). The decrease was observed in adults and children of both sexes (Figs. 2, 3, and 4). However the incidence of STH in children was slightly higher than that in adults, although this difference

Fig. 1 Annual overall rate of soil-transmitted helminthic infection in Nepal.

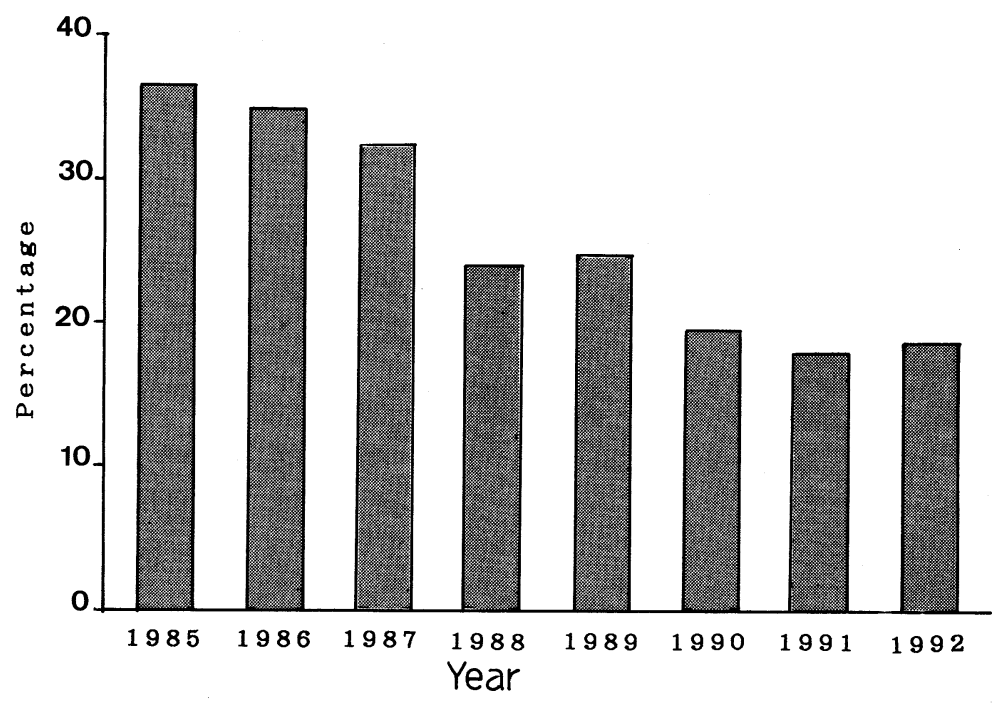

Fig. 2 Annual rate of soil-transmitted helminthic infection in adults and children.

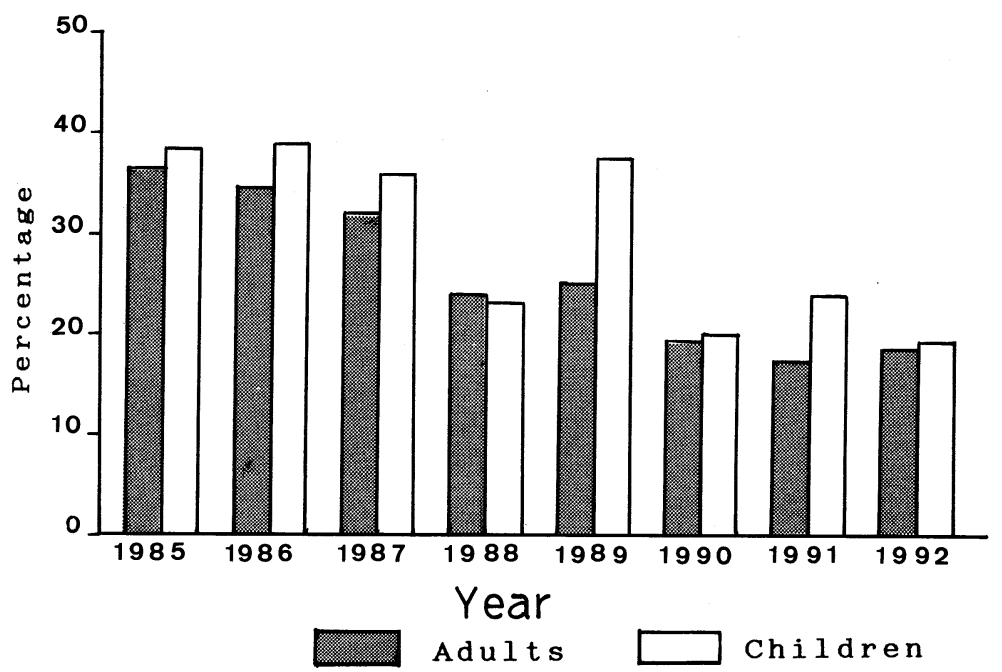


Fig. 3 Annual rate of soil-transmitted helminthic infection in male and female adults.

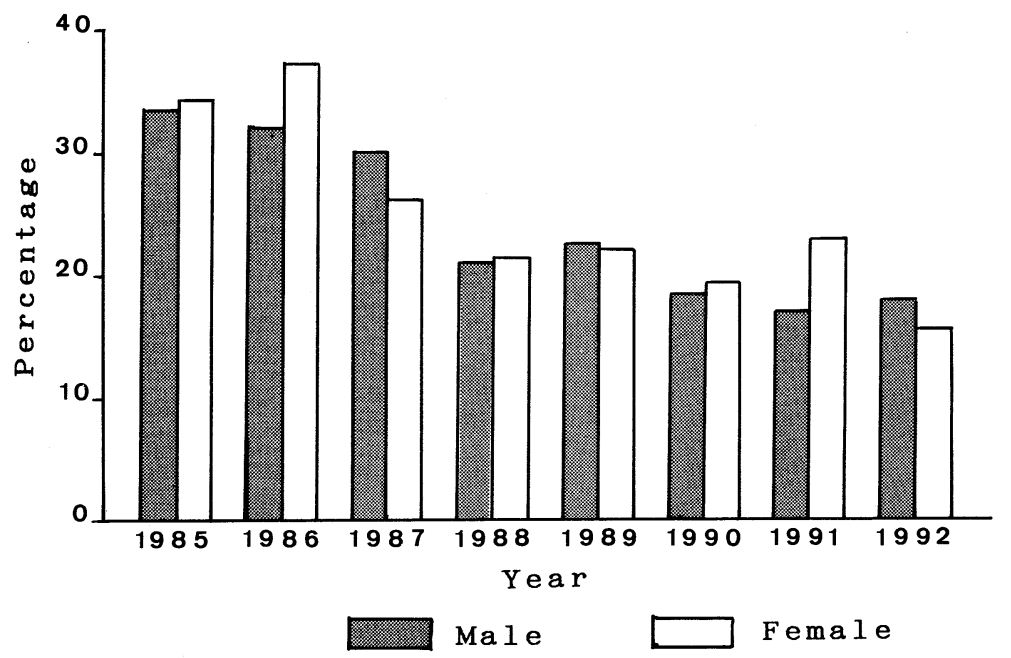

Fig. 4 Annual rate of soil-transmitted helminthic infection in male and female children.

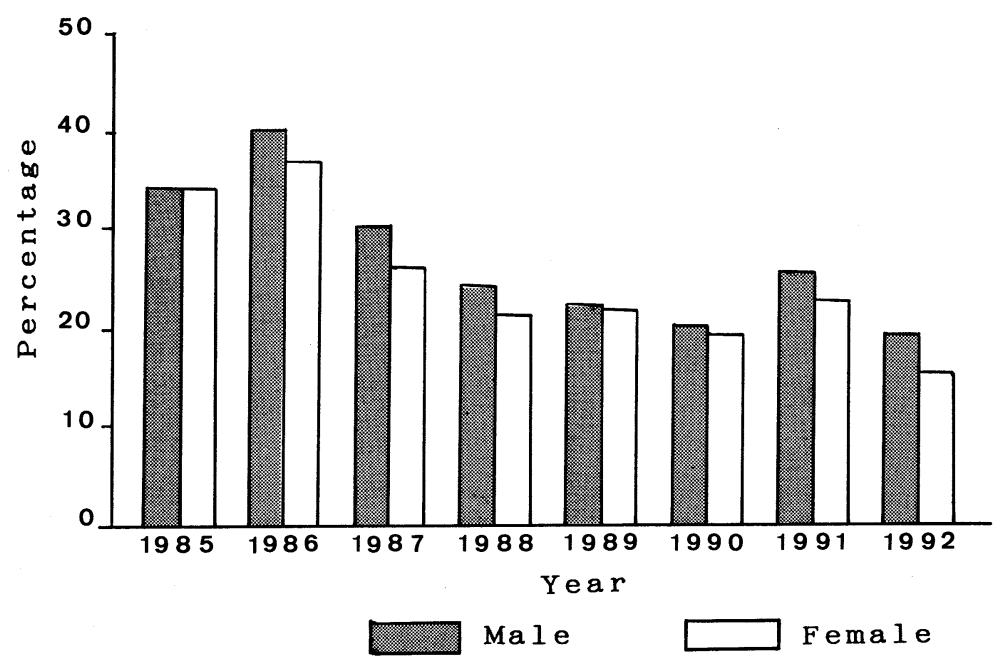

was not significant. Throughout the study period, $A$. lumbricoides was the most commonly detected of the various types of STH, followed by hookworm and T. trichiura (Fig. 5). Interestingly, the incidence of $A$. lumbricoides infection remained constant throughout the study period, while that of other STH infection decreased every year. Strogyloides stercoralis (threadworm) and other STH were very rarely detected, and accounted for less than $0.2 \%$ of the total.

\section{Discussion}

In the present study of the annual prevalence of STH infection in Nepal, a decrease from $36.6 \%$ in 1985 to $18.0 \%$ and $18.7 \%$ in 1991 and 1992 , respectively, was noted. This decrease was due to the marked decrease in the hookworm and $T$. trichiura infection rate. The incidence was not related to age in any year except 1989; we are unable to account for latter finding. In both age groups and sexes, the incidence of STH infection showed yearly decrease, although female adults showed slightly higher incidence than male adults in the years 1986 and 1991. The present findings generally indicate that the incidence of STH in 
Fig. 5 Annual distribution pattern of soil-transmitted helminthic infections in Nepal.

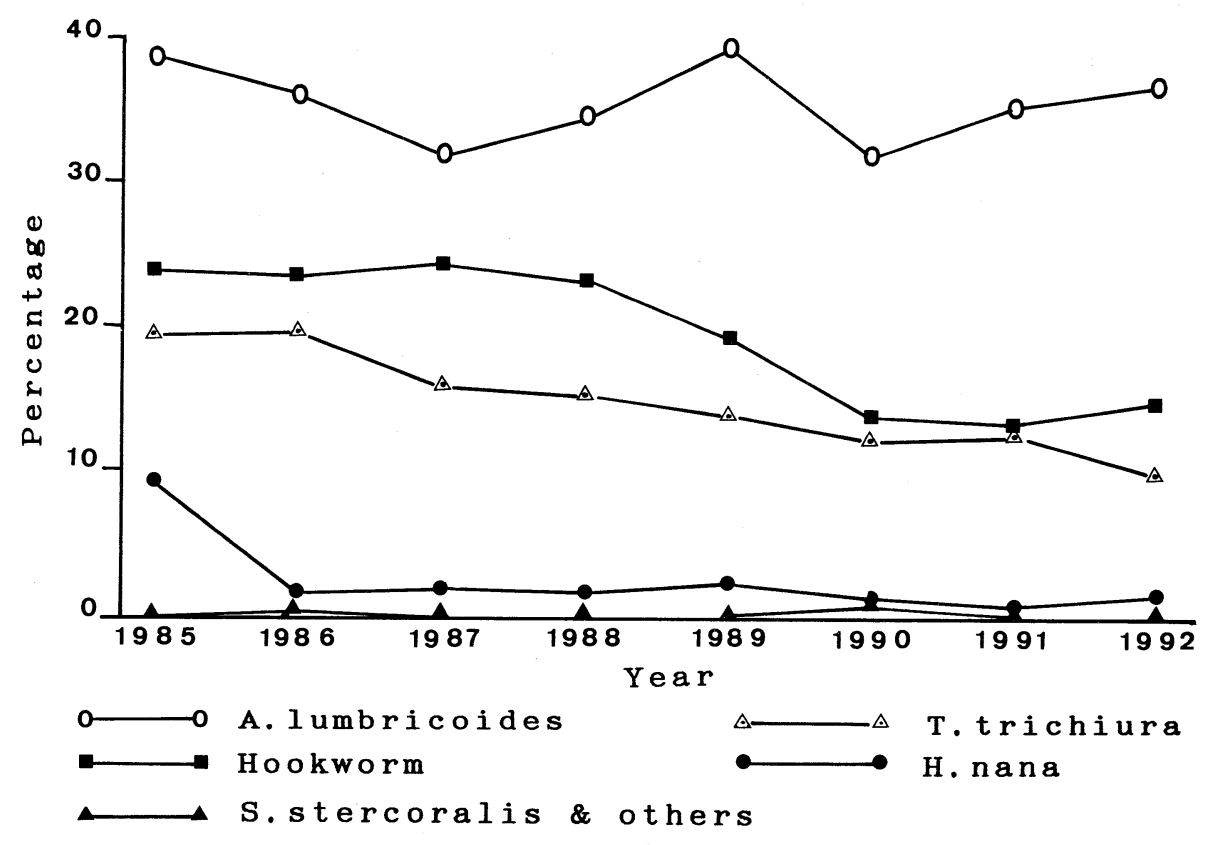

Nepal is declining regardless of age and sex.

Nevertheless, the incidence of $A$. lumbricoides infection was static throughout the study period, as has been found in other studies ${ }^{1}$. This finding is attributed to the widespread dispersion of $A$. lumbricoides within human communities ${ }^{3,13,14,15)}$ and to the heterogenicity of the social, behavioural, and spatial factors that influence the degree of exposure to the infectious organism ${ }^{14,15}$. To a certain degree, an increase in urbanization, may also have contributed to this constant rate of $A$. lumbricoides infection ${ }^{16)}$. The finding that $A$. lumbricoides was the most commonly detected STH in this study is in agreement with other reports regarding Nepal ${ }^{5,6,7,8,9,10,11)}$. In certain localities of Nepal, the reported incidence of $A$. lumbricoides is as high as $90.0 \% 6,9,10)$. This high incidence has been attributed mainly to poor hygiene, lack of sanitary facilities, and use of night-soil without pre-treatment as fertiliser. However, the rate of $A$. lumbricoides-associated morbidity and mortality is not well understood at present. It remains to be elucidated to what extent the situation in Nepal parallels that in Burma, where $55.0 \%$ of all admissions to a pediatric surgical ward were found to be due solely to $A$. lumbricoides infection ${ }^{17}$.

As has been described in various other reports $5,6,7,8,9,10,11)$, the rate of hookworm infection was found to rank second after that of $A$. lumbricoides infection. Hookworm infection is regarded to be the most common etiology of iron-deficiency anaemia in Nepal. The marked decreased incidence of infection with this parasite during the study period might be attributed to the recent widespread adoption of the custom of wearing shoes and/or slippers, which prevent skin penetration by hookworm filariform larvae. Since the species-specific incidence of hookworm infection in Nepal is unknown, we are presently conducting a study of this issue.

T. trichiura was found to be the third most commonly detected STH in Nepal, as has been described in previous reports regarding not only Nepal ${ }^{5,6,7,8,9,10,11)}$ but also other countries ${ }^{18}$. The mode of infection of $T$. trichiura is similar to that of $A$. lumbricoides and the marked decrease in its incidence, which is like that in the case of hookworm is an unexpected finding. Moreover, in many instances, it is difficult to deworm completely with a single dose of albendazole, particularly in heavy infection. Hymenolepis nana (dwarf 
tapeworm) was the fourth most commonly detected STH. This parasite is found mostly in Asia ${ }^{1)}$. Once $H$. nana is localised inside the human host, internal auto-infection can occur leading to severe infection. This feature contributes to the persistence of this infection and its endemicity in the community. Moreover, in many times it is difficult to deworm with standard drug therapy, as the cysticercoid larvae living inside the villus remain unaffected by the drug. However, in the present study, we found a marked decrease in the incidence of this parasite similar to that for hookworm and T. trichiura, although we are not able to account for the decrease in either T. trichiura or H. nana infection. Other STH, such as S. stercoralis, were detected very rarely, and accounted for less than $0.2 \%$ of the total.

The present study is the first of its kind to examine the year-to-year incidence of STH in Nepal. The rate of detection of STH might have been higher, had the concentration technique been applied to each of the samples or had three consecutive samples from each subject been examined, although we consider the present findings to sufficiently demonstrate the status of STH infection in Nepal. In view of the various morbidities and mortality associated with STH, as well as various factors which affect the rate of infection by STH and other intestinal parasites, effective preventive measures are needed to combat STH-related health and socio-economic problems.

\section{Acknowledgement}

We thank Jagat B. Khadka, Sunil Budhathoki, Kanti Bajracharya and Praveen Pradhan for their help in this study.

\section{References}

1) World Health Organization: Technical Report Series 749, 1987.

2) World Health Organization: Technical Report Series 666, 1981.

3) Pawlowski, Z.S.: Ascariasis. In Tropical and Geographical Medicine. (Warren, K.S. and Mahmoud, A.A.F. ed) p. 369-378, New York: McGraw-Hill, 1990.

4) Warren, K.S. \& Mahmoud, A.A.F.: Tropical and Geographical Medicine. New York: McGraw-Hill, 1984.

5) Rai, S.K.: Helminthic infestation in local Nepalese people. Ankur-Magazine of Inst. Med. Central Campus 4: 69-74, 1980.

6) Rai, S.K. \& Gurung, C.K.: Intestinal parasitic infection in high school level students of Birgunj city. J. Inst. Med. 8: 33-38, 1986.

7) Rai, S.K., Nakanishi, M., Khadka, J., Sharma, C.M., Shrestha, M.K. \& Shrestha, H.G.: Intestinal parasitoses in Kathmandu, Nepal. Abstract book of 4th ASEAN Conference in Med. Lab. Tech. held at Bangkok, Thailand on 1-5 April, 1991.

8) Boll, J.P.M. \& Roder, E.C.: Soil-transmitted nematodes in Lalitpur district, Nepal. J. Inst. Med. 3: 167-178, 1981.

9) Nepal, M. \& Palfy, B.: A study of prevalence of intestinal parasites in the Makankal Panchayat and their relation with haemoglobin levels. J. Inst. Med. 2: 175-182, 1980.

10) Reily, C.: Gorkha Report. Dooly Foundation, Kathmandu, Nepal. 1980.

11) Gianotti, A.: Intestinal parasites of Nepal. J. Nep. Med. Assoc. 28: 242-247, 1990.

12) Cowpen, S.G.: A review of helminthiasis in western region of Neigeria with special reference to Ibadan area. West. Afr. Med. J. 16: 3-11, 1967.

13) Thein-Hlaing, Than-Saw \& Myint-Lin: Reinfection of people with Ascaris lumbricoides following single, 6-months and 12-months interval mass chemotherapy in Okpo village, rural Burma. Trans. Roy. Soc. Trop. Med. Hyg. 81: $140-146,1987$.

14) Anderson, R.M. \& Medley, G.F.: Community control of helminthic infection of man by mass and selective chemotherapy. Parasitol. 90: 629-660, 1985.

15) Anderson, R.M.: The population dynamics and epidemiology of intestinal nematode infection. Trans. Roy. Soc. Trop. Med. Hyg. 80: 686-696, 1986.

16) Crompton, D.W.T. \& Savioli, L.: Intestinal parasitic infection and urbanization. Bull. WHO. 71: 1-7, 1993.

17) Crompton, D.W.T., Nesheim, M. \& Powlowski, Z.S.: Ascariasis and its public health significance. London: Taylor and Francis, 1985.

18) Gilman, R.H., Chong, Y.H., Davis, C., Greenberg, B., Virik, H.K. \& Dixon, H.B.: The adverse consequences of heavy Trichuris trichiura infection. Trans. Roy. Soc. Trop. Med. Hyg. 77: 432-438, 1983. 


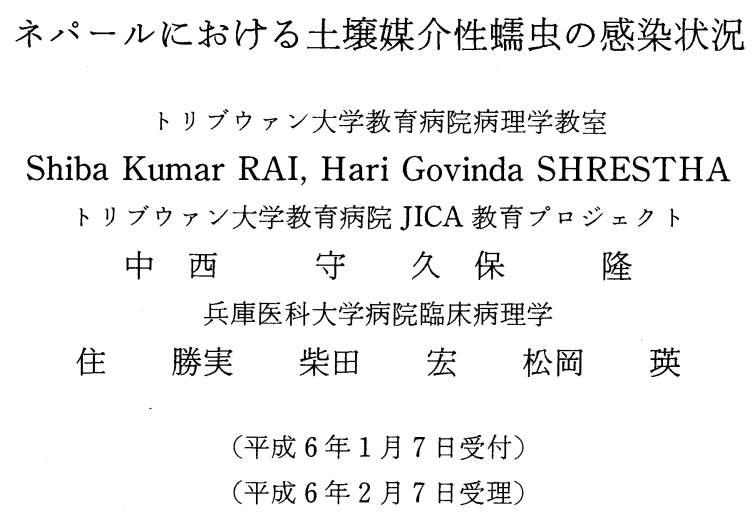

要旨

ネパールに打いて土㗒媒介性蠕虫の感染状況を 8 年間 (1985〜1992) にわたり経年的に調査した。 調査はネパールトリブウァン教育病院の病理学教 室寄生虫検査室により行われ, 毎年平均 6,573 件の 粪便検体からの種々の腸内寄生虫を検出した。そ の結果, 土壤媒介性蠕虫全体の検出率は一様でな
く, 18.0 36.6\%の範囲で経年的に減少した。こ の傾向は性別に関係なく, 成人・小児両方に見ら れた。検出された蠕虫の中では回虫 (roundworm) の検出率が最も高く, 続いて鉤虫, その他の順で あった。本調査期間を通じて回虫の検出率が一定 であったのに対し，他の寄生虫では検出率が低下 するという注目すべき事実が認められた。 